\title{
THE INFLUENCE OF PLANTING DATES AND DOSES OF FERTILIZERS ON THE INFECTION OF POTATO SPROUTS WITH RHISOCTONIA SOLANI KUHN AND MISCELLANEUS ROT TYPES
}

\author{
R. V. Ilchuk, L. A. Ilchuk \\ Institute for Agriculture of Carpathian Region of NAAS \\ 5, Hrushevskoho Str., Obroshyno village, Pustomytivskyi district, Lviv region, 81115, Ukraine; \\ e-mail: roman_ilchuk@ukr.net
}

The determination of optimal timing for potato planting was studied in numerous researches. Their main conclusion is the following: the best term is when soil is heated to the depth of $10 \mathrm{~cm}$ at $7-8^{\circ} \mathrm{C}[1 ; 2]$. At this, not only general climatic conditions are taken into account but microclimatic conditions of the territory, weather conditions and potato varietal features.

Optimal timing for planting potato is accompanied by the most favourable conditions of moisture, warmth, light, intensity of nutrients that provide productivity growth [3-5].

According to M. N. Vasylieva [6], early planting of early-season varieties contributed to a significant increase of productivity, whereas at early planting of middle-late potato varieties the yield, on the contrary, decreased. The author explains it that middle-late potato varieties when planting in early periods at low soil temperatures germinate weakly and are exposed to decay comparatively more often than early-season varieties.

Potato yield losses from diseases and pests, according to official statistics in different countries make up a third. The main reasons for this - viral $(5 \%)$, bacterial $(3 \%)$, fungous (7\%) and other diseases.

N. A. Dorozhkin, S. I. Remnieva [7] indicate that potato tuber lesions with black scrab sclerotia (fungus Rhizoctonia Solani Kuhn) is greatly increased with prolonged stay of tubers on potato haulm after its dyingoff. Experiments of S. M. Tupenevych [8], F. Ya. Novikov, N. V. Bordukova $[9 ; 10]$ found that manure application increased and fertilizers application - significantly reduced the number of tubers affected by common scab.

A number of researchers proved that for highly efficient use of fertilizers biological features of varieties and their reaction to the dose of fertilizer have great importance. The study of biological features of varieties as for different fertilizer standards shows that not only between the varieties of different maturity groups, but also in the maturity group there is a difference in the optimal levels of nutrition. In this regard, the most efficient and cost-effective dose of fertilizer is that supplies a separate variety within the standards and ratios of mineral nutrition [11; 12].

The objective of the work was to establish optimal conditions for potato growing, which would increase yields, reduced thin plantings and their lesion with diseases.

Materials and methods. Experiments were conducted during 2003-2005 in 4-field rotation of the Potato-growing laboratory of the Institute for Agriculture of Carpathian Region of NAAS with the following crop rotation:

1 - green manure crops (winter rape),

2 - potato,

3 - winter wheat,

4 - vetch-oat mixture (for herbage).

The scheme of three-factor experiment included:

1. Planting periods:

- I period (the earliest possible),

- II period (10 days after the I),

- III period (10 days after the II),

- IV period (10 days after the III).

2. The doses of fertilizers:

- Without fertilizer (control),

- $40 \mathrm{t} /$ ha of manure (background),

- background $+\mathrm{N}_{60} \mathrm{P}_{60} \mathrm{~K}_{90}$,

- background $+\mathrm{N}_{90} \mathrm{P}_{90} \mathrm{~K}_{120}$,

- background $+\mathrm{N}_{120} \mathrm{P}_{120} \mathrm{~K}_{180}$.

3. Potato varieties: Serpanok;

- early-season varieties - Nevska,

- middle-season varieties - Slava, Lehenda. 
The area of plots of the $1^{\text {st }}$ order (variety) $-105 \mathrm{~m}^{2}, 2^{\text {nd }}$ order (levels of nutrition) $-35 \mathrm{~m}^{2}$.

The area under the experiment -0.15 hectares, variants placement - randomized.

Mineral fertilizers were applied in the form of compound NPK fertilizer, lack of potassium was balanced with potassium magnesia.

Thus, for potato varieties, depending on the maturity group, such set of agricultural practices for potato growing should be chosen, which provide optimum conditions for reducing thin plantings and survival of plants during the growing season.

The infection of potato planting material depends on the planting timing, doses of fertilizers and maturity groups of varieties. The largest $(2.8-3.7 \%)$ amount of tubers infected with Rhizoctonia Solani Kuhn was observed in the variants with early planting dates. At late planting the reduced tubers infection with black scab was observed, along with increased mouldering of planting tubers from $0.4 \%$ to $7.2 \%$ especially for early maturing varieties. Higher tubers infection $(2.2-2.6 \%)$ with black scab was noticed in variants with manure application (40 t/ha). Application of mineral fertilizers on manure background had resulted in the decrease of black scab infection of tubers by $0.8-0.9 \%$. 